
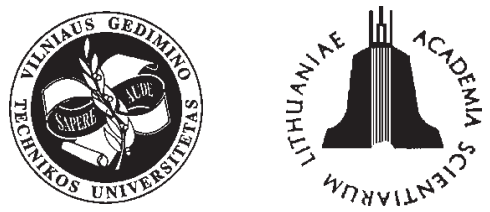

ISSN 1392-3730 print / ISSN 1822-3605 online

JOURNAL OF CIVIL ENGINEERING AND MANAGEMENT

http:/www.jcem.vgtu.lt

2006, Vol XII, No 1, 5-13

Energy production and supply

\title{
SMALL-SCALE CO-GENERATION FOR BUILDING APPLICATIONS - ENERGY DEMAND ANALYSIS AT DEMONSTRATION SITE AND OPTIMAL SIZING OF THE CHP PLANT
}

\author{
Jacek Kalina, Janusz Skorek \\ Division of Thermodynamics and Gas Energy, Institute of Thermal Technology, Silesian University of Technology, \\ 44-100 Gliwice, Konarskiego 22,Poland.E-mail: kalina@itc.polsl.pl,skorek@itc.polsl.pl
}

Received 03 March 2005; accepted 13 Dec 2005

\begin{abstract}
Aspects of using the small-scale combined heat and power modules in buildings is presented in this paper. At first the problems of energy demand analysis, which is the key point of a co-generation plant sizing procedure, are discused. Then the demonstration project of a small-scale co-generation plant is presented. The plant is fuelled with natural gas, and it supplies energy to a group of three different buildings. Basing on this case, the problems of optimal sizing of a small-scale CHP plant for a building energy supply system are presented and discussed. Calculation procedures are shown together with the results of sample analysis. The factors influencing the final configuration of the system are indicated.
\end{abstract}

Keywords: co-generation, buildings, energy demand, electricity and heat load variations, optimization, gas engines, gas boilers, gas turbines.

\section{Introduction}

Combined production of heat and power (CHP) at small-scale plants, that is based on either gas engines or gas turbines, is one of the most effective energy conversion technology to cover simultaneous and suitable demand for heat (cold) and electricity.

In Western countries a lot of projects have been realised in buildings. This is the sector where the simultaneous demand occurs for heat, electricity and sometimes cold. In many cases either co-generation or trigeneration plant can be set up as a main source of energy for building. Current experience in this field has proved that the best locations for co-generation technology are hospitals, schools and universities, commercial buildings, sport centres, hotels and other public and residential buildings.

In Poland at the end of 2003 there were more than 90 CHP plants in operation. Several projects are at the development stage.

Co-generation usually makes a technically possible solution for energy supply in the sector of building. Although the technology itself brings many technical and ecological advantages, the number of installation in some countries is not significant enough (in comparison to an existing potential). There are still barriers on the market that prevent co-generation from rapid development as well as problems related to the realisation of the projects.
During many discussions it has been found that it is highly recommended to work out a number of demonstration projects that would lead to the know-how in the field of small-scale co-generation technology. It is definitely necessary to develop guidelines, standard procedures information database that will help designers, engineers and investors to build up and operate the CHP plants.

It is a complex and not easy task to realise a good and successful project. The experience shows that problems begin at the stage of the energy demand analysis. There are usually also difficulties with selection of the optimal type and size of the machinery and optimal configuration of the system. On the other hand, the best results can be obtained only if the system is optimised under certain technical and economic circumstances [1]. The objective function for optimisation is typically the economic one (eg the maximum value of the NPV index).

In this paper the problem of optimal sizing of a small-scale CHP plant for building energy supply system is being discussed by the example of demonstration project. The project consists in design and installation of CHP plant that would meet the heat and electricity demands of the group of three different buildings. In the first part of the paper the energy demand analysis is presented. In the second part the sizing procedure of the plant is based on the daily heat and electricity load profiles. Finally, the example of calculation results is given. 


\section{Demonstration project}

The demonstration project consists in optimal design and installation of the small-scale co-generation plant fuelled with natural gas. The site is located in South Poland. The plant will supply heat and electricity to the complex of three buildings:

- sport centre with a swimming pool (about $28000 \mathrm{~m}^{3}$ ),

- building of a new modern school (21 $\left.242 \mathrm{~m}^{3}\right)$,

- building of the old school $\left(3400 \mathrm{~m}^{3}\right)$.

At the moment the existing buildings are being fed with electricity from the utility grid, whereas heat is produced at the local coal-fired boiler plant.

The energy system is being planned to work either parallel to the grid or in an island mode. Fig 1 shows the existing buildings and the drawing of a sport centre being designed.
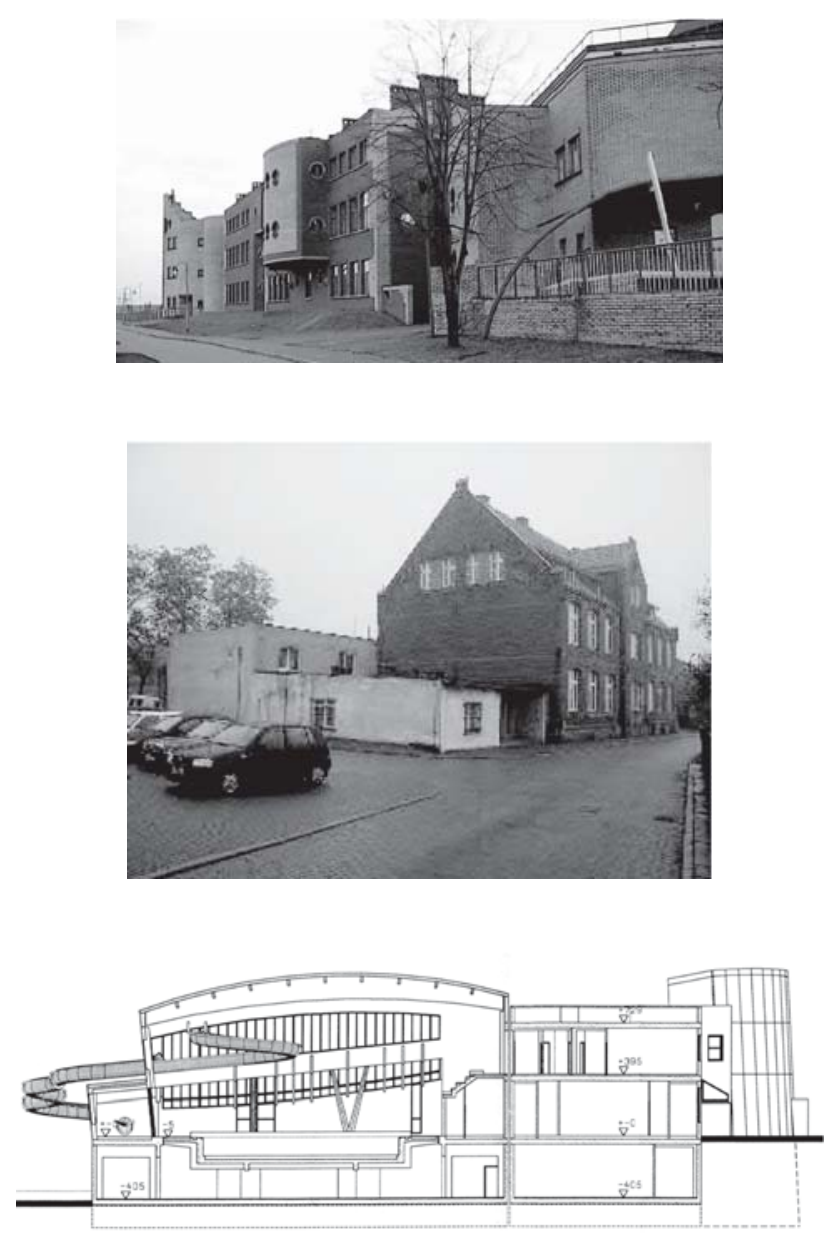

Fig 1. The site

The research and demonstration project includes several tasks:

- elaboration of the methodology of load variation analysis under specific location characteristics in the situation that no monitoring system exists in the group of buildings,
- analysis of energy and regulation characteristics of machinery and devices,

- integration of the co-generation plant to the heat and electricity users,

- elaboration of the methodology of optimal operation of the plant and load sharing procedures,

- optimisation of the energy plant,

- analysis of the local and global technical and ecological effects of the project,

- long-term monitoring of the co-generation plant as well as the total system.

The realisation of the project has been started and it is planned to demonstrate all stages of it.

\section{Energy demand analysis}

There are several energy users at the site of analysed CHP plant:

- school facilities - two buildings (demand for electricity, heating and hot water),

- kitchen and canteen (demand for electricity, heating and hot water),

- swimming pool (demand for electricity and heat for technology),

- sport centre (demand for electricity, heating, hot water, ventilation and air conditioning),

- energy plant (own consumption of energy).

Each of the presented consumers has its own characteristics of daily and seasonal load variations. Maximal, minimal and average energy demand it is not a simple sum of demands that occur at particular objects (users). The peak demands at particular objects typically occur at different day time as the type of activities and time schedule of each object is different. Therefore, in this case the CHP plant sizing procedure must be based on daily load profiles of heat and electricity. The total load must be a sum of individual loads at a particular time. Basing on daily load profiles, the annual heat and electricity load duration curves can be worked out for the planned CHP plant. Using these curves it is possible to identify the expected maximum and minimum demands as well as the total annual consumption of energy.

The main problems with the estimation of daily load profiles result from the facts that the sport centre does not exist yet, there is no monitoring of energy consumption at the school buildings and it is not possible to measure heat consumption at school buildings without disassembly of the heating system. Therefore the following procedure was applied for estimating the daily load profiles of consumers:

- electricity meters at school buildings were read more frequently with an assumed time step,

- maximum heat demand for school buildings was calculated theoretically basing on building construction data,

- annual heat consumption at school buildings was calculated using the ambient temperature variations (monitored at the nearest municipal boiler plant), 
- in order to verify the estimated annual heat consumption at the school buildings, the annual coal consumption at school boiler plant was analysed together with the typical characteristics of coal fired grate-type boilers,

- daily heat load profiles of school buildings were worked out by a typical model [2],

- measurements of heat and electricity consumption were carried out at a similar sport centre (almost twin-object from the same design office),

- registered data of daily heat and electricity consumption at similar sport centre, for the whole year period, were used (Fig 2),

- dimensionless models of load variations were worked out for each consumer.

a) heat

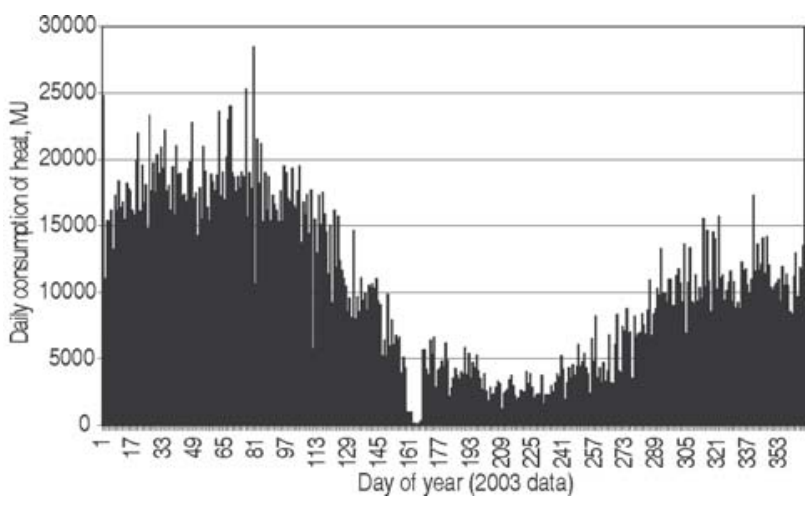

b) electricity

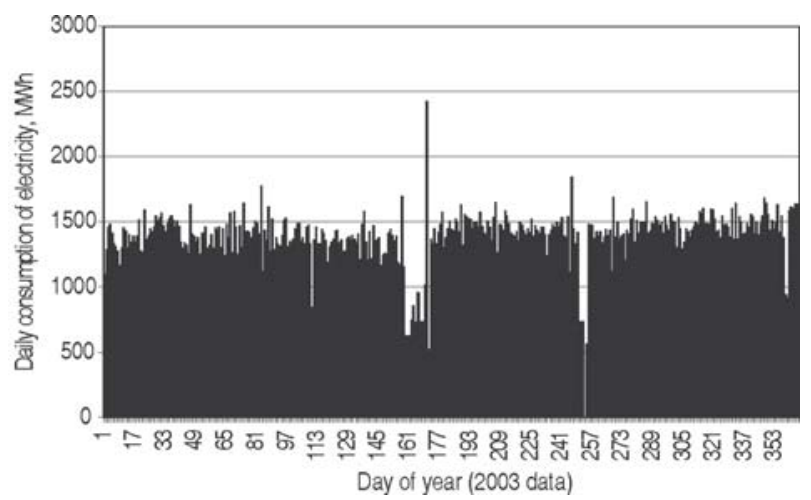

Fig 2. Daily heat and electricity consumption at a similar sport centre

The most important for CHP module sizing procedure are daily load profiles of particular energy users. The models were developed in a dimensionless form. It was observed that during some periods of a year as well as during selected typical days the dimensionless models were similar. Examples of the dimensionless models are shown in Figs 3 and 4.

The accuracy of the energy consumption and daily load profiles is higher if more periods, that are either typical or representative, are taken into account. Typically the models of daily profiles of energy consumption should be elaborated for a different type of days (week- a)

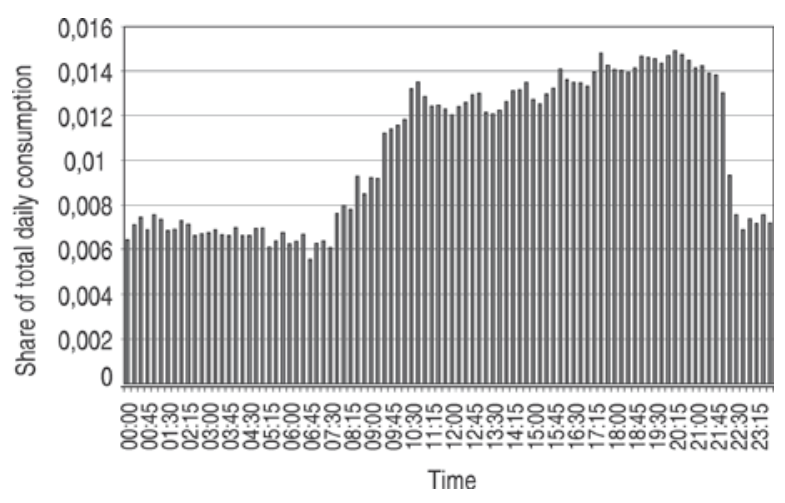

b)

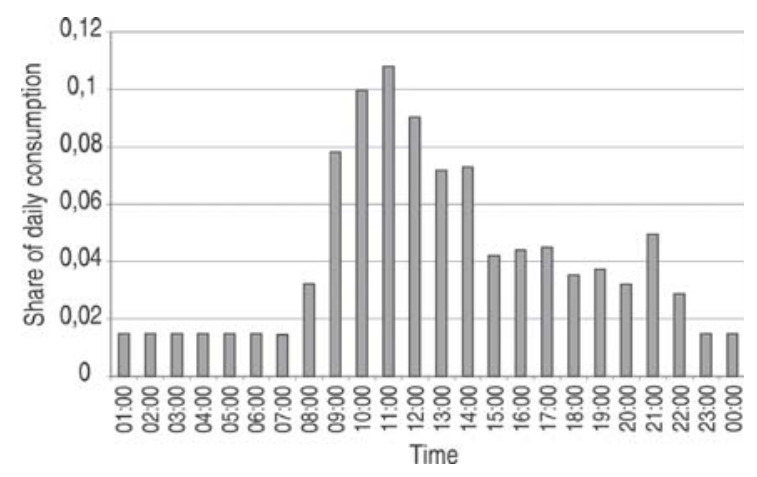

c)

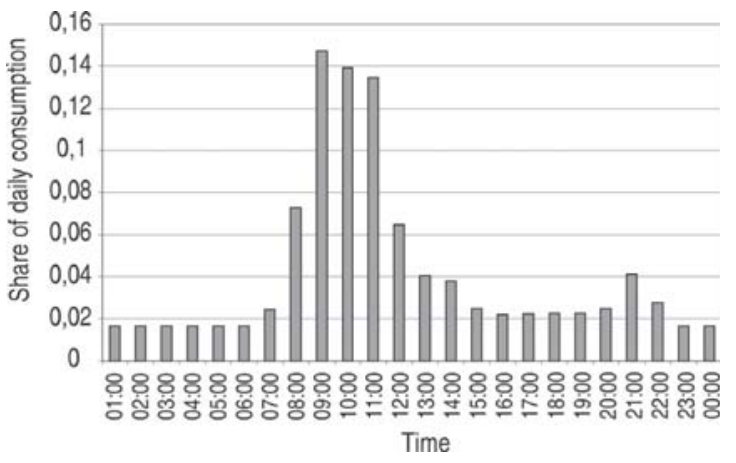

d)

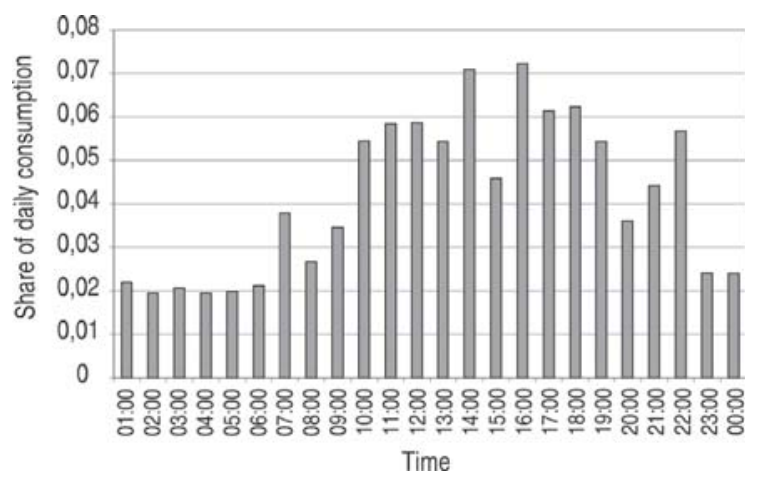

Fig 3. Daily electricity consumption models in the analysed buildings: a) sport centre, b) schools, c) kitchen and canteen, d) boiler plant 
a)

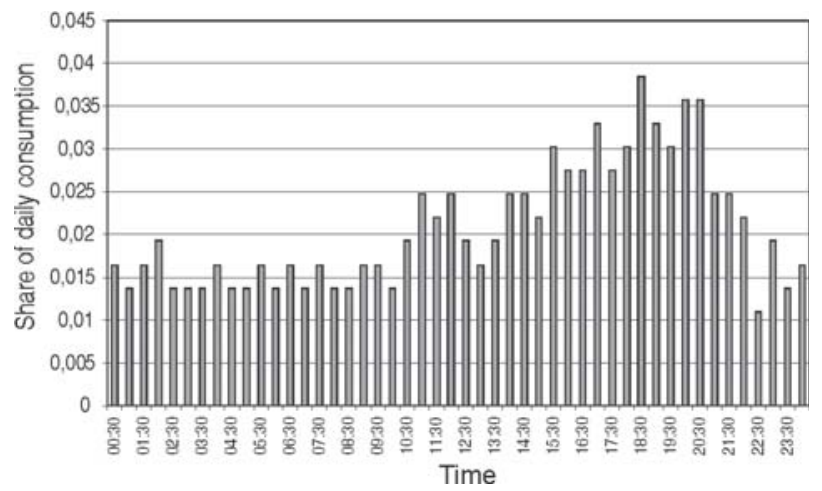

b)

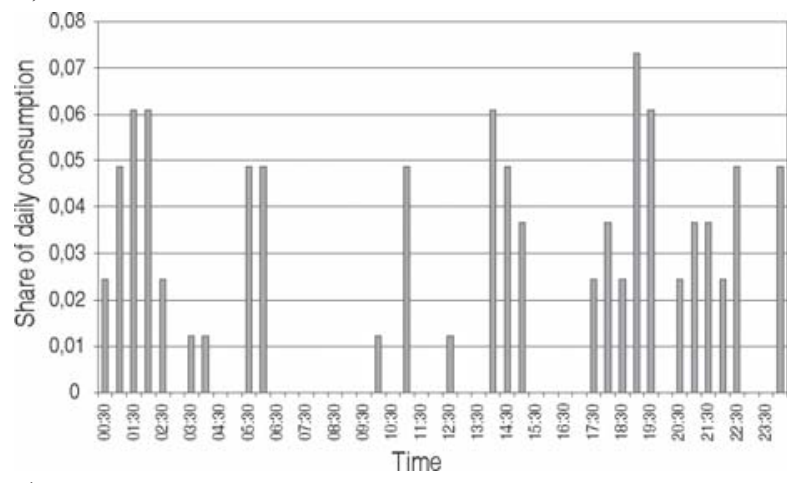

c)

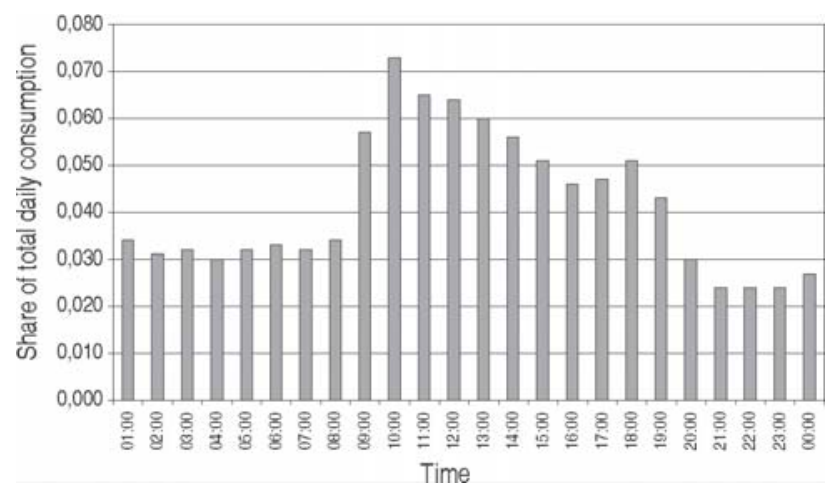

Fig 4. Daily heat consumption models in the analysed buildings: a) sport centre - hot water, heating and ventilation, b) sport centre - technology of swimming pool, c) schools - total consumption

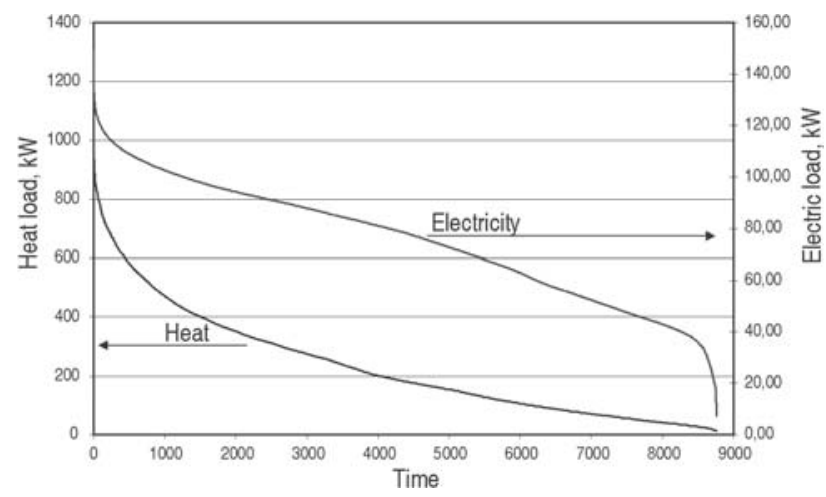

Fig 5. Load duration curves for the analysed buildings days, weekends, holidays etc). Additionally, weekly and monthly models of energy consumption were worked out. Then the load duration curves for heat and electricity were calculated (Fig 5). Parameters of the on-site-energyconsumption characteristics are shown in Table 1.

Table 1. Characteristics of total energy consumption

\begin{tabular}{l|c|c}
\hline \multicolumn{1}{c|}{ Parameter } & Heat & Electricity \\
\hline Maximum demand & $1217 \mathrm{~kW}$ & $149 \mathrm{~kW}$ \\
\hline Minimum demand & $10,8 \mathrm{~kW}$ & $7,2 \mathrm{~kW}$ \\
\hline Average demand & $232 \mathrm{~kW}$ & $75 \mathrm{~kW}$ \\
\hline Total consumption & $7326 \mathrm{GJ}$ & $661637 \mathrm{kWh}$ \\
\hline
\end{tabular}

\section{Optimization of the energy supply system}

Schematic diagram of the heat and power plant is shown in Fig 6. It has been assumed that the system is based on the natural gas fired reciprocating engine. It was found from the energy demand analysis that only microturbines or fuel cells can be an alternative solution in this case. However, both turbines and fuel cells are much more expensive than engines, what makes the economic effect of the project worse.

In order to meet heating demand of the consumers the plant produces hot water that is subsequently fed into the local heating network of $90 / 70{ }^{\circ} \mathrm{C}$ temperature characteristics (at external temperature $-20{ }^{\circ} \mathrm{C}$ ). In case of installation of the CHP module, the electricity is transmitted via common bus to either the consumers or to the external grid operated by the electricity company. In case of electricity shortages, the bus can be also supplied with power from the grid.

The objective function for the plant optimisation procedure is the Net Present Value of the project for specific time of economic life (typically $\mathrm{N}=15$ years) $[1,3,4]$ :

$$
\mathrm{NPV}=\sum_{t=1}^{N} \frac{\mathrm{CF}_{t}}{(1+r)^{t}}-J_{0} \rightarrow \max
$$

The objective function is typically constrained by technical parameters of the plant and the economic environment. The main constraints usually are:

- the demand level for electricity, heat and cold,

- daily and seasonal variations of thermal and electric loads,

- variations of ambient conditions,

- fuel and energy prices,

- daily variations of prices (especially price of electricity),

- annual period of operation,

- mode of operation (priority heat, priority electricity, economic etc),

- type of operation (island or parallel with the mains),

- possibility of sale of the surplus electricity,

- machinery characteristics,

- investment costs,

- operation and maintenance costs,

- environmental costs etc. 


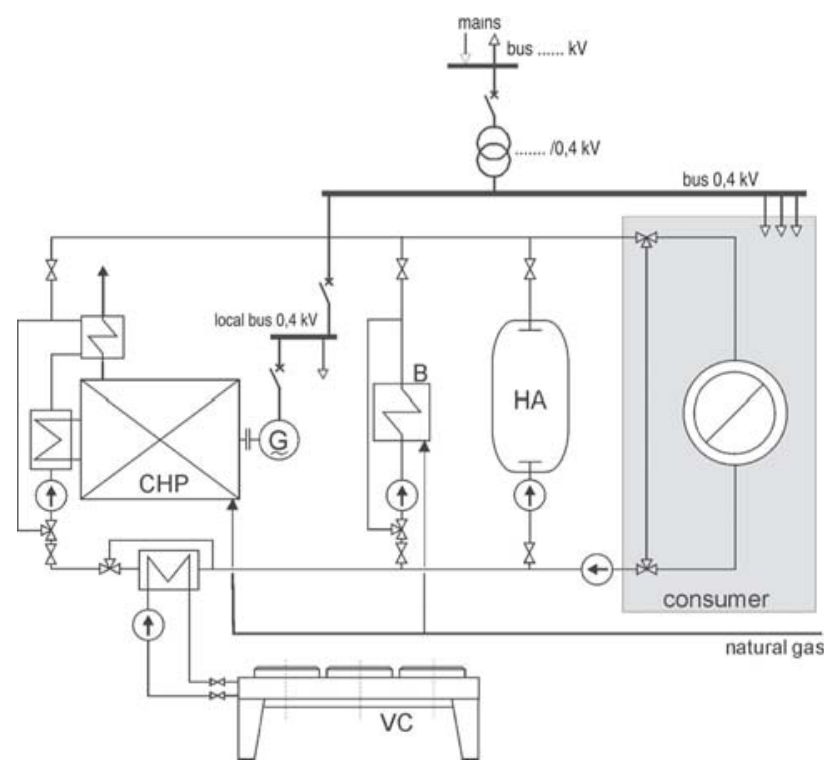

Fig 6. Co-generation plant (CHP - co-generation module, $\mathrm{B}$ - gas boiler; VC - ventilator cooler, HA - heat accumulator, $\mathrm{G}$ - generator)

The complete analysis consists of two integral parts: technical analysis and economic analysis. Scheme of the optimization algorithm is shown in Fig 7.

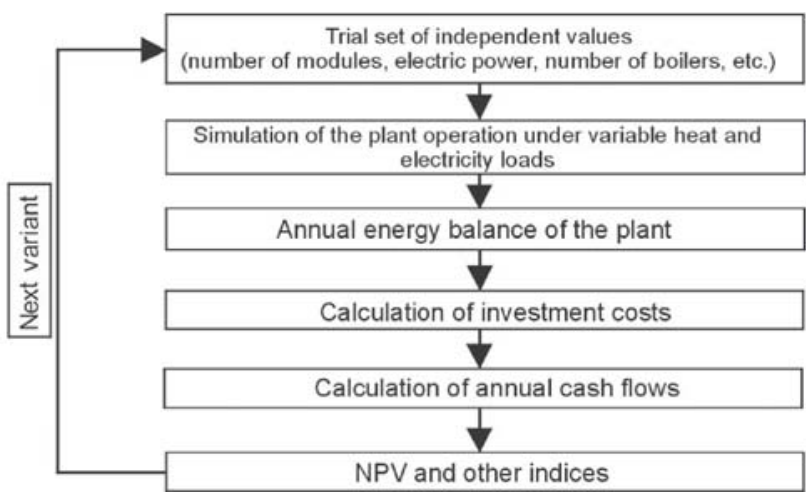

Fig 7. Block diagram of plant sizing optimisation procedure

Momentary energy balance for the entire CHP plant can be written as:

$$
\dot{P} W_{d}+\delta N_{G}=N_{D}-(\delta-1) N_{S}+\dot{Q}_{D}+\dot{Q}_{s t r} .
$$

Then particular elements of the eq 2 can be decomposed as follows:

$$
\begin{gathered}
N_{D}=\sum_{i=1}^{n_{C H P}} N_{C H P i}+\delta N_{G}+(\delta-1) N_{S}-\sum_{k=1}^{n_{P}} N_{P j}, \\
\dot{Q}_{D}=\sum_{i=1}^{n_{C H P}} \dot{Q}_{C H P i}+\sum_{j=1}^{n_{K}} \dot{Q}_{K j}-\dot{Q}_{s t r}+\Delta \dot{Q},
\end{gathered}
$$

$$
\begin{aligned}
& \dot{P} W_{d}=\sum_{i=1}^{n_{C H P}}\left(\dot{P} W_{d}\right)_{C H P i}+\sum_{j=1}^{n_{K}}\left(\dot{P} W_{d}\right)_{K j}= \\
& \sum_{i=1}^{n_{C H P}} \frac{N_{C H P i}}{\eta_{E_{-} C H P i}}+\sum_{j=1}^{n_{K}} \frac{\dot{Q}_{K j}}{\eta_{E k j}} .
\end{aligned}
$$

Ratio of electricity and heat for CHP plant is expressed by the co-generation index $\sigma$ :

$$
\sigma_{i}=\frac{N_{C H P i}}{\dot{Q}_{C H P i}} .
$$

The minimum value of the co-generation index $\sigma$ is limited by the maximal possible heat output of the particular gas engine.

Particular parameters of the machinery characteristics $\left(\eta_{E_{-} C H P}, \sigma\right)$ typically depend on the nominal electric power and momentary load.

In order to estimate heat output and fuel energy consumption at partial loads, the following dimensionless characteristics of the CHP module have been used:

$$
\begin{aligned}
& \frac{\eta_{E_{-} C H P}}{\left(\eta_{E_{-} C H P}\right)_{\text {nom }}}=0,0025\left(\xi_{e l}\right)^{3}-0,2431\left(\xi_{e l}\right)^{2}+ \\
& 0,587\left(\xi_{e l}\right)+0,6537,
\end{aligned}
$$

$$
\begin{aligned}
& \frac{\sigma}{\sigma_{\text {nom }}}=0,8147\left(\xi_{e l}\right)^{3}-1,9848\left(\xi_{e l}\right)^{2}+ \\
& 1,7756\left(\xi_{e l}\right)+0,3968,
\end{aligned}
$$

where $\xi_{e l}=\frac{N_{e l}}{N_{e l} \text { nom }}-$ dimensionless load, $\xi_{e l}=0,2-1$.

It was found from the heat load duration curve that the maximum heat demand occurs only during a very short period of time over the year. Therefore it is needless to size the heating system for maximum load as it will mostly operate at partial load (with lower efficiency). It is usually possible that the building designer allows shortages of heat in some periods. These allowances must be known at the stage of planning the heating system. The temporary heat shortages $\Delta \dot{Q}$ can be included in energy balance of the plant:

$$
\Delta \dot{Q}=\alpha \dot{Q}_{D}
$$

The $\alpha$ index must be controlled over all period of the simulation of plant operation. If the value of the index or the time of its appearance exceed the set up limits, the system must be configured again.

Each machine or device can operate only within the defined range of allowable load. It means that the following inequality constraints have to be taken into account:

$$
\begin{gathered}
\left(N_{C H P i}\right)_{\min } \leq N_{C H P i} \leq\left(N_{C H P i}\right)_{n o m}, \\
\left(\dot{Q}_{K j}\right)_{\min } \leq \dot{Q}_{K j} \leq\left(\dot{Q}_{K j}\right)_{n o m} .
\end{gathered}
$$


If the local co-generation system has to meet simultaneous demands for heat and electricity, there can be defined 9 cases of relations between the heat and electricity demands and the production capacities of the plant [3]. It was found that the priority of the system operation strongly influences the final economic effect of the project [3]. There are several possible modes of CHP module operation. In this paper the following modes are taken into account:

1) electricity tracking (ET) - in this mode the priority is electricity production. The power of the co-generation module is following the demand of the consumer. There is no transfer of surplus electricity to the external utility grid. Heat demand is balanced by the boiler or heat storage tank. If there is a surplus heat, it is dissipated into the atmosphere;

2) heat tracking (HT) - in this mode the priority is heat production. The heat output of the co-generation module is following the demand of the consumer. CHP module usually operates in parallel with boilers. Electricity demand is balanced by the grid;

3) full load operation (FL) - co-generation module is run at full load, no matter what the demand of the consumer is. The momentary energy balance of the plant converges by the cooperation with grid, boilers, storage tanks, ventilator coolers and other devices.

Almost each co-generation module equipped with standard automatic control system can run in the above defined modes.

Optimization of the plant was done by searching for the best solution within the predefined range of trial variants. Energy balance calculations were performed as an "hour by hour" simulation of the plant operation $[3,5]$. The analysis was carried out with using an Excel spreadsheet and Visual Basic macros. Columns of the spreadsheet (matrix) represented particular positions of equations (2)-(5), whereas the rows represented time.

Once the annual energy balance of the plant is done, the economic analysis starts.

The economic analysis basis on the cash flow CF calculation for the whole lifetime of the project:

$$
\mathrm{CF}=\sum_{t=0}^{N} C F_{t}=\sum_{t=0}^{N}\left(-J_{0}+S_{n}-\left(K_{E}+K_{o p}+S_{R}\right)-P_{d}+L\right)_{t} \text {. }
$$

In order to estimate investment costs $J_{0}$, the typical curves of unitary cost $i$ were used:

a) for gas boilers (boiler purchase cost, $\mathrm{zt} / \mathrm{kW}$ )

$$
i=250 \dot{Q}_{\text {nom }}{ }^{-0,13} \text {, }
$$

where $\dot{Q}_{\text {nom }}$ denotes nominal heat output in $\mathrm{kW}$. Heat output range $50 \mathrm{~kW}$ to $10000 \mathrm{~kW}$.

b) co-generation module with gas engine (together with ventilator cooler) - unitary cost in US $\$ / \mathrm{kW}$ within the electric power range $9 \mathrm{~kW}$ to $6000 \mathrm{~kW}$ :

$$
i=2594,9\left(N_{\text {nom }}\right)^{-0,2857} \text {. }
$$

All additional costs were estimated either with using a typical cost breakdown or the offers from vendors. It appeared that equipment purchase cost lays down typically in the range of $40 \%$ to $60 \%$ of the total investment cost $J_{0}$.

In our case real incomes appear only for HT or FL modes of co-generation module operation. The income results from the sale of the electricity surplus to the grid and it is calculated as follows:

$$
S_{n}=\int_{0}^{\tau_{R}} N_{S} d \tau
$$

Total exploitation cost can be expressed as follows:

$$
K_{E}=K_{e n}+K_{O \& M}+K_{p}+K_{s r} .
$$

The most important is the cost of energy:

$$
\begin{aligned}
& K_{e n}=\int_{0}^{\tau_{R}} \dot{K}_{e n} d \tau=\int_{0}^{\tau_{R}}\left(\sum_{i=1}^{n_{C H P}} \frac{N_{C H P i}}{L H V_{C H P} \eta_{E_{-} C H P i}} k_{f C H P}+\right. \\
& \left.\sum_{j=1}^{n_{K}} \frac{\dot{Q}_{K j}}{L H V_{k} \eta_{E k j}} k_{f k}+N_{G} k_{e l}(\tau)\right) d \tau .
\end{aligned}
$$

Operating and maintenance costs were calculated with using the typical index of unitary costs for gas engines $k_{O \& M}=0,007$ to $0,02 \mathrm{US} \$ / \mathrm{kWh}$ (at annual availability in the range of 92-97\%). Therefore the following equation can be used:

$$
K_{O \& M}=E_{e l} k_{O \& M}=k_{O \& M} \int_{0}^{\tau_{R}} \sum_{i=1}^{n_{C H P}} N_{C H P i} d \tau .
$$

Environmental costs are given by equation

$$
\begin{aligned}
& K_{e n v}=\int_{0}^{\tau_{R}} \dot{K}_{e n v} d \tau= \\
& \sum_{i=1}^{n} \int_{0}^{\tau_{R}}\left[\left(\dot{G}_{P i_{-} C H P}+\dot{G}_{P i_{-} k}\right) k_{P i}\right] d \tau+\int_{0}^{\tau_{R}} \dot{G}_{W} k_{W} d \tau .
\end{aligned}
$$

Typically $\dot{G}_{P i_{-} C H P}, \dot{G}_{P_{-} B}$ are calculated with using emission indices for a particular machinery type. Emission fees in Poland are regulated by the government: $\mathrm{SO}_{2}-0,38 \mathrm{PLN} / \mathrm{kg} ; \mathrm{CO}_{2}-0,00020 \mathrm{PLN} / \mathrm{kg} ; \mathrm{CH}_{4}$ - 0,00020 PLN/kg; $\mathrm{NO}_{2}-0,38 \mathrm{PLN} / \mathrm{kg} ; \mathrm{CO}-0,10 \mathrm{PLN} /$ $\mathrm{kg} ; \mathrm{NMHC}-0,10 \mathrm{PLN} / \mathrm{kg}$; dust - 0,25 PLN/kg (Note: $4,2 \mathrm{zl}=1$ EURO).

\section{Case study}

In the reference case of calculations it has been assumed that no co-generation module will be installed on site. The existing coal fired boiler plant will be replaced with gas boiler plant, electricity will be purchased from the utility grid separately for each building. Proposed gas boiler plant would consist of three gas boiler of respectively 350,350 and $200 \mathrm{~kW}$ heat output. Fuel and energy prices, that were used in the analysis, are as follows: 
- Natural gas price depends on an annual consumption, average value is: $0,796 \mathrm{PLN} / \mathrm{Nm}^{3}$.

- Electricity price: - sport centre (tariff C21): 328,67 PLN/MWh; - school (tariff C11): 336,17 PLN/ MWh.

Technical and economic results of the project are given in Table 2.

Table 2. Results of technical and economic analysis for base case project

\begin{tabular}{c|l|l|c}
\hline No & \multicolumn{1}{|c|}{ Quantity } & Unit & Value \\
\hline 1 & $\begin{array}{l}\text { Amount of heat produced at boiler } \\
\text { plant }\end{array}$ & $\mathrm{GJ} / \mathrm{a}$ & 7272 \\
\hline 2 & Heat shortage & $\mathrm{GJ} / \mathrm{a}$ & 54 \\
\hline 3 & $\begin{array}{l}\text { Total amount of electricity from } \\
\text { utility grid }\end{array}$ & $\mathrm{kWh} / \mathrm{a}$ & 661637 \\
\hline 4 & Total amount of natural gas burned & $\mathrm{Nm}^{3} / \mathrm{a}$ & 230871 \\
\hline 5 & $\begin{array}{l}\text { Average efficiency of the boiler } \\
\text { plant }\end{array}$ & $\%$ & 90,7 \\
\hline 6 & Total cost of electricity & PLN/a & 218600 \\
\hline 7 & Total cost of natural gas & PLN/a & 183750 \\
\hline 8 & Investment cost & PLN & 466540 \\
\hline 9 & Net Present Value after 15 years & PLN & -3463600 \\
\hline
\end{tabular}

Table 3 presents the configurations of the co-generation plant that were defined as trial solutions for optimization procedure.

Table 3. Selected variants of the configuration of the plant

\begin{tabular}{|c|c|c|c|c|c|c|c|c|c|c|c|}
\hline \multirow{2}{*}{$\begin{array}{l}\text { Nominal } \\
\text { parameter }\end{array}$} & \multicolumn{11}{|c|}{ Number of variant } \\
\hline & 1 & 2 & 3 & 4 & 5 & 6 & 7 & 8 & 9 & 10 & 11 \\
\hline $\mathrm{N}_{\mathrm{CHP}} \mathrm{kW}$ & 20 & 30 & 40 & 50 & 60 & 70 & 80 & 90 & 100 & 110 & 120 \\
\hline$\dot{Q}_{C H P} \mathrm{~kW}$ & 44 & 62 & 79 & 96 & 112 & 128 & 143 & 158 & 173 & 188 & 203 \\
\hline$\dot{Q}_{K 1} \quad \mathrm{~kW}$ & 350 & 350 & 350 & 350 & 350 & 350 & 350 & 350 & 330 & 300 & 300 \\
\hline$\dot{Q}_{K 2} \quad \mathrm{~kW}$ & 350 & 350 & 300 & 300 & 300 & 285 & 275 & 260 & 260 & 260 & 250 \\
\hline$\dot{Q}_{K 3} \quad \mathrm{~kW}$ & 160 & 140 & 170 & 155 & 140 & 140 & 140 & 140 & 140 & 150 & 150 \\
\hline
\end{tabular}

It was assumed that there will be only one co-generation module. The minimal allowable electric load of the module was set in the value of $40 \%$ of nominal power. Figs 8 and 9 show the results of technical analysis. In the electricity tracking mode there is no sale of the electricity surplus electricity to the grid, however, if the installed electric power of the CHP module is higher, the production is much lower than potentially possible (compare to FL mode). On the other hand, in the ET mode the loss of heat form CHP module is lower.

In the HT and FL modes of CHP module operation, the electricity can be sold to the mains. If so, the selling price of surplus electricity will be $140 \mathrm{PLN} / \mathrm{MWh}$.

Fig 10 shows the results of the economic analysis in relation to the reference case. It was found that the best mode of operation of the CHP module is electricity tracking. It was also found that there is an optimal solution that consists in installation of CHP module in $80-$ $90 \mathrm{~kW}$ electric power range and three gas boilers. The difference in NPV comparing to base case analysis is at the level of investment cost.
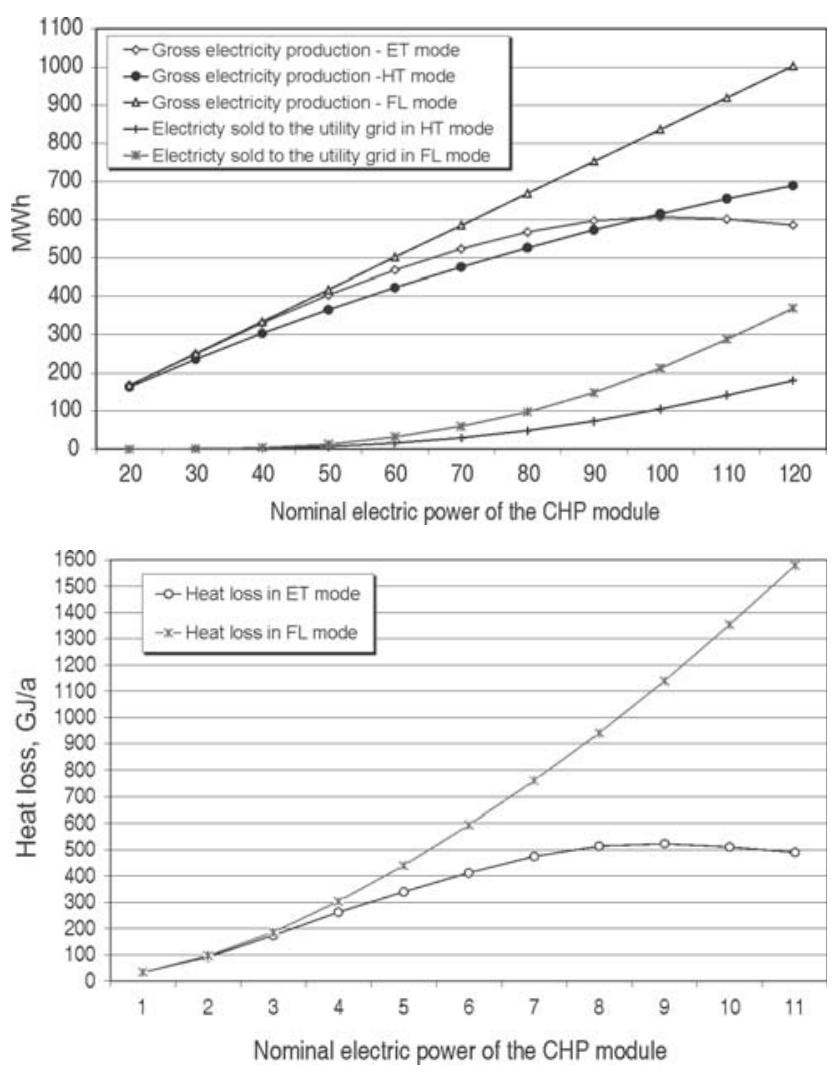

Fig 8. On-site electricity production and heat loss in particular variants of the plant configuration
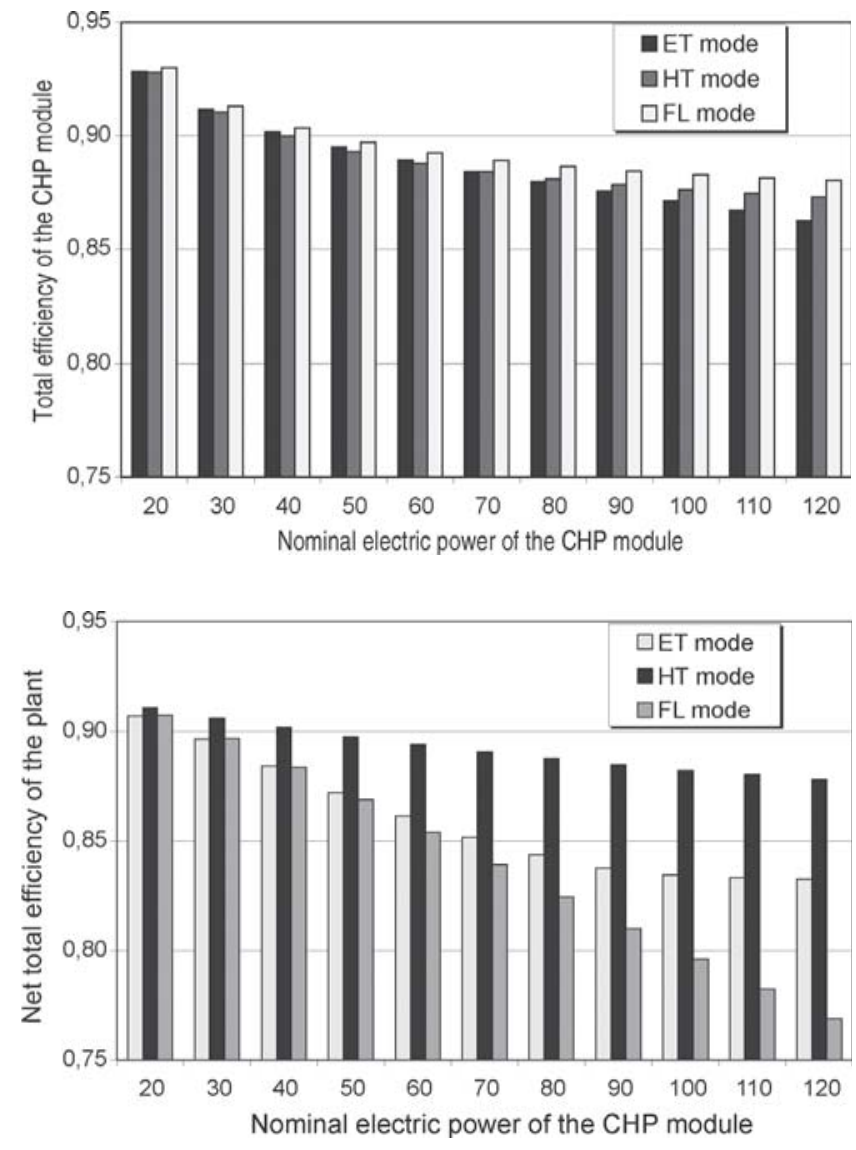

Fig 9. Total efficiency (EUF) of the co-generation module and the whole plant 


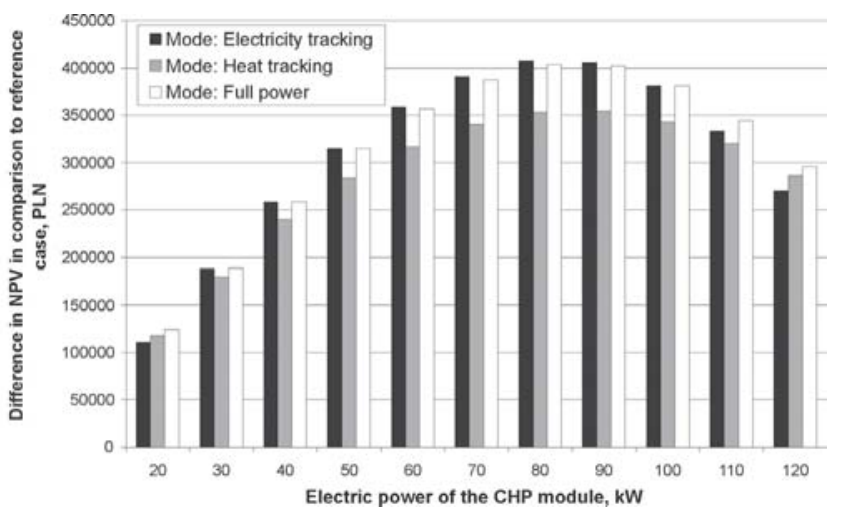

Fig 10. Results of the optimization procedure

\section{Conclusions}

Co-generation is the simultaneous production of heat and electricity in a single plant. Therefore, in order to ensure technical and economic effectiveness of a project, the simultaneous demand for both heat and electricity must occur on the site of energy user.

The demand for heat and electricity at any object is never constant. If a CHP plant is considered to be installed at a local energy system, it is necessary to work out the daily heat and electricity load profiles of the consumer. Only in this case it can be estimated if both useful products of co-generation module can be fully utilised, what is the remaining demand for electricity from the utility grid and for heat from boilers, in what hours the CHP module can be switched on and off, if there is a need for heat storage tank and what the total cost of energy supply will be.

In our demonstration project, the analysis of energy was quite complicated and time consuming task. This is mainly because no historical data of energy consumption in buildings was available. On the other hand, this is the typical situation if the new building is planned or if the outdated energy system is going to be replaced with modern small-scale co-generation plant. As it was presented, the simplified procedure of estimation the shape of daily load profiles can be applied in such case.

Considering the heat and electricity load profiles, that we have obtained for the demonstration site, it appeared that the two functional types of objects represent two different characteristics of energy consumption. In school buildings the peak demands occur rather in morning hours, whereas the sport centre requires more energy in evenings. In both cases there were quite significant differences between peak and off-peak demands.

A very interesting profile was obtained for heat consumption for the swimming pool technology (Fig 5). As the swimming pool itself is a large heat reservoir with high inertia, the heating system runs periodically. It suggests that the heat storage tank can be necessary in order to ensure full utilisation of heat from co-generation module.

The example of the optimal sizing of a co-generation plant demonstrated that the optimal solution exists and it can be initially identified by using a general model

\section{Nomenclature}

$C F_{t} \quad$ cash flow in year $t$

$G_{P} \quad$ mass flow of pollutant

$\dot{G}_{W} \quad$ mass flow of water

$J_{0} \quad$ investment capital

$K_{E} \quad$ costs of exploitation

$K_{e n} \quad$ cost of energy

$K_{\text {env }} \quad$ environmental cost

$K_{o p} \quad$ operational costs

$K_{O \& M} \quad$ operation and maintenance cost

$K_{p} \quad$ labour cost

$k_{f C H P}, k_{f k}$ cost of fuels

$\mathrm{k}_{e l}(\tau) \quad$ cost of electricity, variable in time according to tariffs

$\begin{array}{ll}\text { Greek sy mbols } \\ \alpha & \text { index of allowable heat shortage } \alpha \in\langle 0,1\rangle \\ & \text { energy production efficiency } \\ \eta_{E} & \text { binary variable } \\ \delta & \text { time } \\ \tau & \text { annual time of the operation } \\ \tau_{\mathrm{R}} & \end{array}$

$\begin{array}{ll}k_{P i} & \text { unitary emission fees } \\ k_{W} & \text { unitary cost of water } \\ L & \text { salvage value } \\ N & \text { electric power or lifetime of the project } \\ P_{d} & \text { income tax } \\ \dot{P} W_{d} & \text { stream of chemical energy of fuel } \\ \dot{Q} & \text { heat flux } \\ \dot{Q}_{N} & \text { momentary heat shortage } \\ r & \text { discounted cash flow rate } \\ S_{n} & \text { incomes } \\ S_{R} & \text { economic losses resulted from heat } \\ \mathrm{W}_{\mathrm{d}} & \text { shortages } \\ & \text { lower heating value of fuel (LHV) }\end{array}$

\section{Subscripts}

CHP related to CHP module

$D \quad$ related to demand site

$\mathrm{G} \quad$ related to utility grid

$K \quad$ related to boiler

$P \quad$ plant self use of electricty

$S \quad$ sale

str losses

min minimal

nom nominal

$i, j, k \quad$ related to $i$-th, $j$-th,$k$-th module 
of the plant and statistical parameters of machinery characteristics. The presented model is also suitable for selecting the optimal mode of the co-generation module operation.

Although the procedure is not a complicated one and quite effective, it must be emphasised that it is only the first step of the analysis. In the next stage technical and economic data for specific engines and boilers have to taken from vendors. General characteristics have to be replaced by the real ones and the whole calculation has to be done again. In some cases the technical and economic real effects can be even more attractive than that one obtained from pre-feasibility study.

For the analysed case the initial study has proved that that the co-generation makes better solution than the boiler plant only.

\section{References}

1. Kalina, J. Analysis and optimization of the small-scale combined heat and power systems. PhD thesis. Silesian Technical University at Gliwice, Poland. Gliwice, 2001.
2. Institut Wallon. Demande de chaleur techniquement cogenerable pour la region Wallonne et la region de Bruxelles Capitale. Raport final. Mai 1997, Namur, Belgium.

3. Kalina, J. Initial sizing of the heat and electricity source under known daily load profiles - Simplified equation based analysis. In: Proceedings of the Seminar co-generation in industrial and municipal energy systems. Gliwice, Poland, 2003. Skorek J. Analysis of technical and economic effectiveness of small-scale co-generation plants fuelled with gaseous fuels. Silesian University of Technology Publishing, Gliwice, 2002 (in Polish).

4. Yokoyama, R.; Ito, K. Multi-objective optimization in unit sizing of a gas turbine cogeneration plant. Journal of Engineering for Gas Turbines and Power, Vol 117. Styczeń, 1995.

5. Witzani, M.; Pechtl, P. Modelling of (co-generation)-power plants on time dependent power demands of the consumer. In: Materiały konferencji ASME Cogen-Turbo Conference. Wiedeń, Austria, August 1995.

This work has been supported by the Polish Committee for Scientific Research under the research grant No 4 T10B 02225.

\section{NEDIDELIU MASTELIU KOGENERACIJOS PRITAIKYMAS PASTATUOSE - DEMONSTRACINE் ENERGIJOS POREIKIU巳 ANALIZE் IR OPTIMALUS KOGENERACINĖS JĖGAINĖS DYDIS}

\section{J. Kalina, J. Skorek}

Santrauka

Pateikiami nedidelių mastelių mišrieji pastatų šilumos ir elektros moduliai. Visų pirma atliekama energijos poreikių analizè, kuri svarbi pasirenkant kogeneracinès jẻgainès dydị. Pateiktas nedidelių mastelių kogeneracinès jègainès demonstracinis projektas. Jègainė užpildyta gamtinėmis dujomis ir tiekia energiją trims skirtingoms pastatu grupèms. Darbe aprašomos ir nagrinėjamos optimalios nedidelių mastelių kogeneracinès jègainès, aprūpinančios pastatus energija, dydžio parinkimo problemos. Skaičiavimu procedūros pateikiamos kartu su bandymų analizès rezultatais. Apžvelgti pagrindiniai veiksniai, darantys ittaką galutinei kogeneracinẻs sistemos konfigūracijai.

Raktažodžiai: kogeneracija, pastatai, energijos poreikiai, elektros ir šilumos galios pokyčiai, optimizacija, dujų varikliai, garo katilai, dujų turbinos.

Jacek KALINA. MSc, PhD, DEng, Assistant Professor at the Institute of Thermal Technology, Silesian University of Technology at Gliwice, Poland. Fields of interest: energy engineering, mathematical modelling of industrial energy systems, combined production of heat and power, trigeneration, gaseous fuels fuelled energy systems, industrial energy audits, design and optimization of small-scale CHP systems, computer programming, using commercial computer software for modelling thermal energy systems.

Janusz SKOREK has been working at the Silesian University of Technology in Gliwice, Poland. Since 2000 he is Head of the Department of Thermodynamics and Gas Energy of the Institute of Thermal Technology where he set up the research group involved into complex problems of distributed heat and power generation based on gaseous fuels and gas distribution engineering. His field of scientific activities includes mathematical modelling of complex thermal processes and systems, direct and inverse problems of heat transfer, nuclear engineering, technical and economical problems of distributed power generation. He is the author and co-author of more than 200 research and technical papers and 5 books. Except for educational activities at the university he has been involved into a great number of projects for industry including technical and economical studies of gas supplied CHP systems. 